\title{
DAMPAK KEPEMILIKAN MANAJER DAN UTANG TERHADAP KEMAMPULABAAN PERUSAHAAN
}

(Studi kasus pada perusahaan manufaktur di BEI tahun 2003-2010).

Oleh:

Iwan Dermawan

\section{Abstract}

This empirical study aims to examine the relationship manager ownership (KSM) and debt (Lev), and the effect of stock manager ownership and debt to the company's ability of profitable (ROA). The study shows that managers stock ownership variables associated negative and significant with debt. While the effect of stock ownership by managers and debt to the company ability of profitable (ROA) negative and significant results.

Keywords: the company ability of profitable (ROA), stock ownership by manager (KSM) and debt (Lev).

\section{Pendahuluan}

Brigham dan Enhard (2003), mengatakan bahwa informasi akuntasi mengenai kegiatan operasi perusahaan dan posisi keuangan perusahaan dapat diperoleh dari laporan keuangan. Informasi akuntansi berupa laporan keuangan sangat penting bagi para pelaku bisnis seperti investor dalam pengambilan keputusan. Para investor akan menanamkan investasinya pada perusahaan yang dapat memberikan return yang tinggi.

Financial Accounting Standards Board (FASB) (1978), Statement of Financial Accounting Concepts No. 1, menyatakan bahwa fokus utama laporan keuangan adalah laba, jadi informasi laporan keuangan seharusnya mempunyai kemampuan untuk memprediksi laba di masa depan. Laba sebagai suatu pengukuran kinerja perusahaan merefleksikan terjadinya proses peningkatan atau penurunan modal dari berbagai sumber transaksi (Takarini dan Ekawati, 2003). Laba perusahaan diharapkan setiap periode akan mengalami kenaikan, sehingga dibutuhkan estimasi laba yang akan dicapai perusahaan untuk periode mendatang. Estimasi terhadap laba dapat dilakukan dengan menganalisis laporan keuangan.

Setiap perusahaan selalu
membutuhkan dana operasional untuk membelanjai sehari-hari, misalkan untuk memberikan persekot pembelian bahan mentah, membayar upah buruh, gaji pegawai dan lain sebagainya, di mana uang atau dana yang telah dikeluarkan itu diharapkan akan dapat kembali lagi masuk dalam perusahaan dalam waktu yang pendek melalui hasil penjualan produksinya. Uang yang masuk berasal dari penjualan produk tersebut akan segera dikeluarkan lagi untuk membiayai operasi selanjutnya. Dengan demikian maka dana tersebut akan terus menerus berputar setiap periodenya selama hidupnya perusahaan.
Pilihan yang strategis antara pembiayaan utang dan ekuitas didasarkan pada setiap bentuk pembiayaan jangka panjang. Oleh karena itu, pilihan perusahaan antara utang dan ekuitas harus di analisa kembali dari keputusan strategis membuat perspektif. Kebijakan utang merupakan bagian dari struktur modal perusahaan. Struktur modal adalah penting bagi kelangsungan hidup perusahaan. Secara umum, sebuah perusahaan dapat memilih diantara banyak alternatif struktur modal. Beberapa teori menyatakan bahwa struktur modal perusahaan yang menentukan berbagai biaya dan manfaat, terkait dengan utang dan ekuitas.

Pemegang saham adalah pemilik dari sebuah perseroan terbatas, dan mereka membeli saham karena mereka ingin mendapatkan pengembalian modalnya Pemegang saham akan memilih direksi, yang kemudian akan menunjuk para manajer untuk menjalankan perusahaan secara harian. Manajer bekerja mewakili para pemegang saham, artinya mereka hendaknya mematuhi kebijakan yang dapat meningkatkan nilai para pemegang saham (Brigham dan Houston, 2006).

\section{Landasan teori \\ Utang Perusahaan}

Utang sebagai bagian dari struktur modal perusahaan, mempunyai pengaruh meningkatkan risiko perusahaan karena selain harus membayar pokok pinjaman juga harus membayar bunga. Leyland dan Pyle (1977), menjelaskan penggunaan utang yang melebihi ambang batas tertentu dapat menurunkan nilai perusahaan, hal ini disebabkan karena meningkatnya biaya kebangkrutan.

Utang didalam akuntansi didifinisikan sebagai pengorbanan manfaat ekonomis yang akan datang, yang mungkin terjadi akibat kewajiban suatu badan usaha dimasa kini untuk mentransfer aktiva atau 
menyediakan jasa pada badan usaha lain dimasa yang akan datang sebagai akibat transaksi atau kejadian dimasa lalu (Baridwan, 2000).

Tingkat penggunaan utang sebagai sumber pembiayaan perusahaan disebut leverage (Schall dan Halley, 1992). Perusahaan dengan rasio leverage yang rendah mempunyai risiko kerugian yang lebih kecil pada saat keadaan perekonomian menurun, tetapi juga mengakibatkan rendahnya tingkat hasil pengembalian (return) pada saat perekonomian tinggi. Sebaliknya Perusahaan dengan rasio leverage yang tinggi menghadapi risiko kerugian yang besar tetapi juga kesempatan mendapatkan laba yang tinggi.

\section{Kepemilikan manajer.}

Struktur kepemilikan dapat dijelaskan dari dua sudut pandang (Iturriaga dan Sanz, 1998) yaitu pendekatan keagenan (agency approach) dan pendekatan ketidak seimbangan informasi (asymmetric information approach). Pendekatan keagenan menganggap struktur kepemilikan sebagai sebuah instrument untuk mengurangi konflik kepentingan diantara berbagai pemegang klaim. Pendekatan asymmetric information memandang mekanisme struktur kepemilikan sebagai suatu cara untuk mengurangi ketidak seimbangan informasi antara insiders dan outsiders melalui pengungkapan informasi di dalam pasar modal (Leland dan Pyle, 1997).

Teori keagenan (agency theory) memunculkan argumentasi terhadap adanya konflik antara pemilik yaitu pemegang saham dengan manajer. Konflik tersebut muncul sebagai akibat perbedaan kepentingan diantara kedua belah pihak. Kepemilikan managerial atau kepemilikan insider kemudian dipandang sebagai mekanisme kontrol yang tepat untuk mengurangi konflik tersebut. Dalam hal ini kepemilikan insider dipandang dapat menyamakan kepentingan antara pemilik dan manajer, sehingga semakin tinggi kepemilikan insider akan semakin tinggi pula nilai perusahaan. Shleifer dan Vishny (1986), menyatakan bahwa kepemilikan saham yang besar dari segi nilai ekonomisnya memiliki insentif untuk memonitor. Secara teoritis ketika kepemilikan manajemen rendah, maka insentif terhadap kemungkinan terjadinya perilaku oportunistik manajer akan meningkat. Kepemilikan saham oleh pihak manajemen perusahaan dipandang dapat menyelaraskan potensi perbedaan kepentingan antara pemegang saham luar dengan manajemen (Jansen dan Meckling, 1976). Sehingga permasalahan keagenan diasumsikan akan hilang apabila seorang manajer adalah juga sekaligus sebagai seorang pemilik.
Jensen dan Meckling (1976), Mao (2003), Pawlina dan Renneboog (2005), dan Chen et al. (2006), mengungkapkan bahwa untuk mengurangi agency problem, pihak pemegang saham dapat membatasi kegiatan agen melalui pemberian insentif yang tepat, seperti peningkatan kepemilikan saham perusahaan oleh manajemen. Hal ini dapat diartikulasikan bahwa bahwa proporsi kepemilikan manajer atas saham perusahaan adalah untuk mengatasi konflik keagenan di dalam perusahaan, karena dengan melakukan pendanaan eksternal untuk meningkatkan proporsi kepemilikan manajer atas saham perusahaan dapat memberikan insentif bagi manajer (equity holders' riskshifting incentive)

\section{Kemampu Labaan Perusahaan.}

Kemampu labaan perusahaan adalah ukuran kinerja perusahaan. Kinerja perusahaan merupakan rasio laba bersih dengan total assets perusahaan. Semakin tinggi rasio ini menunjukkan bahwa perusahaan telah dikelola dengan tingkat pengembalian atas assets yang tinggi. Pengukuran kinerja perusahaan dilakukan untuk melakukan perbaikan dan pengendalian atas kegiatan operasionalnya agar dapat bersaing dengan perusahaan lain. Selain itu, pengukuran kinerja juga dibutuhkan untuk menetapkan strategi yang tepat dalam rangka mencapai tujuan perusahaan.

$\begin{array}{ccc}\text { Informasi akuntansi } & \text { sangat } \\ \text { bermanfaat } & \text { untuk } & \text { menilai }\end{array}$
pertanggungjawaban kinerja manajer. Karena penilaian kinerja pada dasarnya merupakan penilaian perilaku manusia dalam melaksanakan peran yang dimainkannya dalam mencapai tujuan organisasi atau perusahaan. Kemungkinan yang lain adalah digunakannya informasi akuntansi bersamaan dengan informasi non akuntansi untuk menilai kinerja manajer atau pimpinan perusahaan. Mulyadi (1997, hal 419) menjelaskan kinerja adalah gambaran pencapaian pelaksanaan suatu kegiatan atau program atau kebijaksanaan dalam mewujudkan sasaran, tujuan, misi dan visi organisasi.

\section{Pengembangan Hipotesis}

Berdasarkan teori keagenan, menjelaskan hubungan antara pemilik dan pengelola dan antara pemilik dan pihak luar (investor dan kreditor), dimana dalam hubungan tersebut terjadi masalah agensi (agency problem). Jensen dan Mekling (1976), mendifinisikan hubungan keagenan sebagai sebuah kontrak dimana satu atau lebih prinsipal menyewa orang lain (agent) untuk melakukan beberapa jasa bagi kepentingan mereka dengan mendelegasikan beberapa wewenang pembuat keputusan 
kepada agen. Hubungan kontraktual ini biasanya dilakukan dengan menggunakan angka-angka akuntansi yang dinyatakan dalam laporan keuangan sebagai dasarnya. Scott (2000), mengatakan pendesainan kontrak yang tepat untuk menselaraskan kepentingan agen dan prinsipal bilamana terjadi konflik kepentingan. Berdasarkan uraian diatas berikut hipotesis yang diformulasikan untuk menguji antara :

\section{Hubungan Kepemilikan Manajer dan Utang}

Jensen dan Meckling (1976); Chrutchley dan Hansen (1989); Jensen, Solberg dan Zorn (1992); Pawlina dan Renneboog (2005); Chen et al (2006), mengungkapkan bahwa untuk mengurangi agency problem dapat dilakukan dengan membatasi kegiatan agen melalui pemberian insentif yang tepat, seperti peningkatan kepemilikan saham perusahaan oleh manajemen.

Sebagian besar literatur mengungkapkan kepemilikan perusahaan dapat diuji melalui sejumlah dimensi, antara lain dengan melihat pengaruh insider dan outsider ownership, board independent, committee Auditor, dan kepemilikan terkonsentrasi. Semakin terkonsentrasi kepemilikan perusahaan pada satu orang maka kendali akan menjadi semakin kuat dan cenderung menekan konflik keagenan. Kepemilikan manajerial merupakan isu penting dalam teori keagenan, bahwa semakin besar proporsi kepemilikan manajemen dalam suatu perusahaan maka manajemen akan berupaya lebih giat untuk memenuhi kepentingan pemegang saham yang juga adalah dirinya sendiri.

Hubungan struktur Kepemilikan dan struktur Modal antara lain hubungan kepemilikan manajerial dan utang, Chen dan Steiner (1999), mengatakan kepemilik-an manajerial dan kebijakan utang memiliki hubungan negatif. Hal ini disebabkan adanya faktor substitusi antara keduanya. Beberapa peneliti menemukan hubungan positif antara kepemilikan manajerial dengan debt ratio perusahaan (Kim dan Sorensen 1986, Agrawal dan Mendelker 1987, Mehran 1998 dalam Wahidahwati 2002, Soliha dan Taswan 2002). Menurut Jensen, Solberg dan Zorn (1992) dalam Crutchley et al (1999), menemukan bahwa kebijakan utang dan dividen tidak mempengaruhi insider ownership, namun insider ownership mempengaruhi pembiayaan dan dividen. Menurut An, Jin and Simon (2006), Insider ownership meningkat atau tinggi akan menurunkan debt to equity ratio /DER. Dari penjelasan dan beberapa penelitian empiris di atas dapat disimpulkan bahwa kebijakan utang perusahaan tanpa kepemilikan manajerial akan berbeda dengan perusahaan dengan kepemilikan manajerial.

Berdasarkan uraian diatas dapat

ditentukan hipotesis 1 sebagai berikut:

H1: Kepemilikan manajerial dan utang memiliki hubungan (asosiasi) yang negatif.

\section{Pengaruh Kepemilikan Manajer terhadap Kemampu Labaan perusahaan.}

Berbagai studi yang mengidentifikasi adanya hubungan positif antara kepemilikan oleh pihak dalam (insider ownership) dengan kinerja perusahaan antara lain dilakukan Kim, Lee dan Francis (1988), Schellenger, Wood dan Tashakori (1989), dan Oswald dan Jahera (1991). Sedang studi lainnya yang menunjukkan hasil kurang mendukung (secara statistik tidak signifikan) atau bertentangan dengan penelitian sebelumnya yaitu dilakukan oleh Lloyd, Jahera dan Goldstein (1986) dan Tsetsekos dan DeFusvo (1990). Studi yang dilakukan mereka menunjukkan bahwa hubungan antara dua faktor, yaitu kepemilikan oleh manajer top terhadap perusahaan dan kinerja perusahaan secara keseluruhan ternyata tidak cukup signifikan. Berdasarkan uraian diatas dapat ditentukan hipotesis 2 sebagai berikut:

H2: Kepemilikan manajerial berpengaruh negatif terhadap Kemampu Labaan/kiner-ja perusahaan.

\section{Pengaruh Utang terhadap Kemampu Labaan perusahaan.}

Kemampu Labaan perusahaan adalah Profitabilitas, didasarkan pada investasi yaitu diukur dari perbandingan antara laba operasi dengan total aktiva: Return On Assets (ROA). Tingkat ROA berpengaruh terhadap kelangsungan hidup perusahaan dimasa yang akan datang. Tingkat ROA yang rendah atau negatif akan menurunkan kemampuan perusahaan untuk tumbuh dan berkembang. Kondisi seperti ini menunjukkan kinerja perusahaan yang buruk akan menurunkan kridibilitas perusahaan untuk mendapatkan dana akibatnya dibutuhkan biaya modal yang lebih besar. Hal ini bisa menurunkan harapan dan keuntungan pemilik dan cenderung menurunkan nilai saham perusahaan.

Hubungan antara profitabilitas dan utang dapat dijelaskan dengan bukti menurut Titman dan Wessels (1988) dan Barton et al. (1989), setuju bahwa keuntungan perusahaan yang tinggi, akan menjaga rasio utang relatif rendah. DeAngelo dan Masulis (1980), Strebulaev (2003) dan Gaud et al. (2005) yang menemukan bahwa terdapat suatu hubungan yang positif antara tingkat leverage dengan profitabilitas perusahaan. Bukti empiris dari studi sebelumnya konsisten dengan sebagian besar studi, menemukan 
hubungan negatif antara profitabilitas dan struktur modal (Friend dan Lang, 1988; Barton et al., 1989; Shydam-Myers, 1999; Van der Wijst dan Thurik, 1993; Chittenden et al., 1996; Mishra dan Mc Conanghy, 1999 Michaelas et al., 1999). Cassar dan Holmes (2003), Esperanca et al., (2003) dan Hall et al., (2004) menyatakan terdapat hubungan negatif antara profitabilitas dan utang jangka pendek. Petersen dan Rajan.

Berdasarkan uraian diatas dapat ditentukan hipotesis 2 sebagai berikut:

H3: Utang berpengaruh negatif terhadap Kemampu

Labaan/kinerja perusahaan.

\section{Metode Penelitiian}

\section{Data Penelitian}

Studi ini menggunakan populasi perusahaan yang berasal dari perusahaan manufaktur yang terdaftar di BEI selama 8 tahun, yaitu tahun 2003-2010. Penelitian ini menggunakan data sekunder, yang diperoleh dari Indonesian Capital Market (ICMD) tahun 2011.

\section{Definisi dan operasional variabel}

Dalam penelitian ini terdapat tiga variabel laten, dua variabel independen (eksogen) yaitu Kepemilikan manajerial dan Utang. Satu variabel dependen (endogen) yaitu Kemampu Labaan/kinerja perusahaan.

- Kepemilikan manajerial sebagai variabel independen (exogen).

Variabel ini merupakan persentase kepemilikan saham yang dimiliki oleh pihak manajemen/manajerial (KSM) yang secara aktif ikut dalam pengambilan keputusan perusahaan (insider ownership/InO) dari seluruh modal saham yang beredar.

- Variabel Utang (Leverage) sebagai variabel independen (exogen)

Variabel struktur modal diproksi dengan Leverage yaitu perbandingan antara total utang dan total aset.

$$
\text { Leverage }=\frac{\text { TotalDebt }}{\text { TotalAssets }}
$$

- Kemampu Labaan/ Profitabilitas sebagai variabel dependen (endogen) Profitabilitas diproksi dengan return on assets (ROA), alasan digunakannya return on assets (ROA) sebagai proksi dari profitabilitas adalah bahwa return on assets (ROA) ini merupakan rasio akuntansi yang paling penting, karena
ROA mengukur kemampuan perusahaan memperoleh laba dari seluruh aset perusahaan yang diinvestasikan dimana pendanaannya menggunakan sumber sebagian besar dari utang dan sebagian sisanya dari equity.

$$
R O A=\frac{E A T}{\text { TotalAssets }}
$$

dimana: $\mathrm{ROA}=$ Return On Assets $\mathrm{EAT}=$ Earning After Tax

\section{Alat Analisis Data dan Olah data.}

Dalam penelitian ini alat analisis data menggunakan alat bantu software SPSS versi 18.0 for Windows. Alat analisis yang akan digunakan untuk mengestimasi Dampak Kepemilikan Saham Manajer dan Utang (Leverage) terhadap kemampu labaan perusahaan (ROA) melalui regresi dan korelasi. Untuk mengetahui pengaruh variabel independen terhadap variabel dependen digunakan model regresi berganda dengan persamaan sebagai berikut:

$$
\begin{aligned}
& \text { ROA = a + b1 KSM + b2Lev } \\
& \text { dimana: ROA = Return On Assets } \\
& \text { KSM = Kepemilikan } \\
& \text { Saham Manajer } \\
& \text { Lev = Ratio Total Debt to Total } \\
& \text { Assets }
\end{aligned}
$$

\section{Hasil Penelitian Dan Pembahasan}

1. Hasil Penelitian

Pengujian Asumsi Klasik

Melalui analisis regresi, untuk menunjukan hubungan yang valid atau tidak bias maka perlu pengujian asumsi klasik pada model regresi yang digunakan yaitu multikolinieritas, autokorelasi dan heterosedakstisitas. Pengujian ini dapat dilakukan dengan alat bantu software SPSS versi 18.0 for windows.

a. Multikolinearitas.

Multikolinieritas menunjukkan adanya hubungan linier yang sempurna diantara variabel independen. Pengujian multikolinieritas menggunakan VIF (variance inflation factor) dengan batas nilai toleransi adalah terendah 0,10 dan tertinggi 10. Gujarati (2003) mengatakan bila nilai VIF lebih besar dari 10 berarti terdapat kolinearitas sangat tinggi.

Tabel 1. Colinearity Statistics (Coefficients) 


\begin{tabular}{|c|c|c|c|c|c|c|c|c|c|c|c|}
\hline \multirow[t]{2}{*}{ Model } & \multicolumn{2}{|c|}{$\begin{array}{l}\text { Unstandardi } \\
\text { zed } \\
\text { Coefficients }\end{array}$} & \multirow{2}{*}{$\begin{array}{l}\text { Standardi } \\
\text { zed } \\
\text { Coefficien } \\
\text { ts } \\
\text { Beta }\end{array}$} & \multirow[b]{2}{*}{$\mathrm{t}$} & \multirow[b]{2}{*}{ Sig. } & \multirow{2}{*}{$\begin{array}{l}95,0 \% \\
\text { Confide } \\
\text { nce } \\
\text { Interval } \\
\text { for B } \\
\\
\text { Upper } \\
\text { Bound }\end{array}$} & \multicolumn{3}{|c|}{ Correlations } & \multicolumn{2}{|c|}{$\begin{array}{l}\text { Collinearity } \\
\text { Statistics }\end{array}$} \\
\hline & $B$ & $\begin{array}{l}\text { Std. } \\
\text { Error }\end{array}$ & & & & & \begin{tabular}{|l} 
Zero \\
- \\
order
\end{tabular} & $\begin{array}{l}\text { Parti } \\
\text { al }\end{array}$ & Part & $\begin{array}{l}\text { Toleran } \\
\text { ce }\end{array}$ & VIF \\
\hline $\begin{array}{l}1 \text { (Constan } \\
\text { t) }\end{array}$ & ,094 & ,009 & & 10,152 & ,000 & ,112 & & & & & \\
\hline KSM &,- 174 & ,047 &,- 247 & $-3,717$ & ,000 &,- 081 &,- 223 &,- 279 &,- 247 & ,997 & 1,003 \\
\hline Lev &,- 114 &, 016 &,- 476 & $-7,157$ & ,000 &,- 082 &,- 464 &,- 488 &,- 476 & ,997 & 1,003 \\
\hline
\end{tabular}

a. Dependent Variable: ROA

Berdasarkan hasil pengujian dengan software SPSS versi 18.0 for windows, menunjukkan bahwa nilai VIF untuk KSM adalah 1.003, dan Lev adalah 1.003 ini berarti model regresi tidak terjadi multikolinieritas karena nilai VIF terletak diantara nilai batas toleransi.

\section{b. Autokorelasi}

Autokorelasi menunjukkan adanya kondisi yang berurutan diantara gangguan atau disturbance ui atau ei yang masuk ke dalam fungsi regresi. Pengujian terjadi autokorelasi apabila nilainya mendekati 0 atau 4 terjadi autokorelasi. Durbin-Watson test digunakan untuk menguji autokorelasi, Gunawan (1999) menjelaskan bahwa autokorelasi tidak terjadi bila DW terletak diantara du (4-du) dan $(d u<D W<4-d u)$.

Tabel 2. Autocorrelations Durbin-Watson Test (Model Summary)

\begin{tabular}{|c|c|c|c|c|c|c|c|c|c|c|}
\hline \multirow[t]{2}{*}{ Model } & \multirow[b]{2}{*}{$\mathrm{R}$} & \multirow[b]{2}{*}{$\begin{array}{l}\mathrm{R} \\
\text { Square }\end{array}$} & \multirow[b]{2}{*}{$\begin{array}{l}\text { Adjusted R } \\
\text { Square }\end{array}$} & \multirow{2}{*}{$\begin{array}{ll}\text { Std. Error } \\
\text { of the } \\
\text { Estimate }\end{array}$} & \multicolumn{5}{|c|}{ Change Statistics } & \multirow[b]{2}{*}{\begin{tabular}{|l} 
Durbin- \\
Watson \\
\end{tabular}} \\
\hline & & & & & \begin{tabular}{|l|} 
R Square \\
Change
\end{tabular} & F Change & df1 & df2 & $\begin{array}{l}\text { Sig. } F \\
\text { Change }\end{array}$ & \\
\hline 1 &, $525^{a}$ & ,276 & ,267 &, 042366 & ,276 & 31,242 & 2 & 164 &, 000 & 1,909 \\
\hline
\end{tabular}

a. Predictors: (Constant), Lev, KSM

b. Dependent Variable: ROA

Berdasarkan hasil pengujian regresi pada Model summary dengan software SPSS versi 18.0 for windows, menunjukkan bahwa nilai Durbin-Watson (DW) adalah 1.909, ini berarti model regresi tidak mengalami autokorelasi karena ratarata nilai Durbin Watson mendekati Hasil uji autokorelasi menunjukkan bahwa Dw = 1.909; atau dapat dituliskan sebagai berikut: $0<1.909<$ 4; ini berarti tidak ada autokorelasi. Dari table 2 diatas, juga dapat menjelaskan goodness of fit melalui hasil $R$ square dan Ftestnya.

c. Heteroskedastisitas

Heteroskedastisitas menunjukkan variansi antar variabel tersebar dan tidak sama. Untuk mendeteksinya dapat menggunakan uji Glejser. Uji Glejser meregresikan nilai absolut residual dengan variabel independennya. Jika nilai t signifikan berarti terjadi heteroskedastisitas.

Berdasarkan hasil pengujian dengan software SPSS versi 18.0 for windows, menunjukkan bahwa signifikansi nilai t dari kedua variabel independen sebesar kurang dari 1 (lihat Tabel 1) artinya model regresi tidak terjadi heteroskedastisi-tas. Dari uji asumsi klasik pada penelitian ini telah memberikan hasil bahwa independent variable memiliki hubungan dan pengaruh terhadap dependent variable.

\section{Hubungan Kepemilikan Saham Manajer dan Utang (Leverage)}

Untuk mengetahui hubungan antar masing-masing variabel independen dengan variabel dependen menggunakan software SPSS versi 18.0 for windows, ditunjukkan tabel 3 berikut ini:

Tabel 3. Correlations 


\begin{tabular}{|ll|l|l|l|}
\hline & & ROA & KSM & Lev \\
\hline Pearson Correlation & ROA & 1,000 &,- 223 &,- 464 \\
& KSM &,- 223 & 1,000 &,- 051 \\
& Lev &,- 464 &,- 051 & 1,000 \\
\hline Sig. (1-tailed) & ROA & - &, 002 &, 000 \\
& KSM &, 002 & - &, 256 \\
& Lev &, 000 &, 256 & - \\
\hline N & ROA & 167 & 167 & 167 \\
& KSM & 167 & 167 & 167 \\
& Lev & 167 & 167 & 167 \\
\hline
\end{tabular}

Dari Tabel 3 diatas dapat diketahui Kepemilikan Saham Manajer dan Lev berhubungan negatif $(-0,051)$. Kepemilikan Saham Manajer dan ROA berhubungan negatif $(-0,223)$ dan Lev dan ROA berhubungan negatif $(-0,464)$

\section{Pemodelan.}

Dari hasil analisis statistik dengan software SPSS versi 18.0 for windows didapat keterangan seperti terlihat pada tabel 1: persamaan regresi berganda linier untuk kasus yang diteliti berdasarkan nilai $B$ (constant) dan konstanta variabel bebas (KSM, Lev dan KLP) adalah sebagai berikut:

ROA $=0.094-0.174$ KSM -0.114

Lev

\section{Pengujian Model Regresi}

Karena asumsi klasik telah terpenuhi, maka pengujian model regresi layak untuk dilakukan.

\section{Pengujian Serentak}

Hasil pengujian model regresi secara serentak melalui Uji $F\left(F_{\text {test }}\right)$ untuk menge-tahui pengaruh variabel bebas secara simultan berpengaruh tehadap variabel terikat, sebagai berikut:

Ho: b1 >= 0 (signifikan)

Ha: $\mathbf{b j} \neq \mathbf{0}$ (tidak signifikan)

$\mathrm{V}_{1}=\mathrm{K}-1=3-1=2$ dan $\mathrm{V}_{2}=\mathrm{K}-3=164$ maka $F_{\text {tabel: }} F_{0.05(2,164)}=3,05$

Hasil $F_{\text {hitung melalui analisis regresi }}$ software SPSS versi 18.0 for windows didapat 31.242 (lihat tabel 2), berdasarkan uji dua pihak: $F_{\text {hitung }}$ $(=31,242)>F_{\text {tabel }}(=3,05)$ diterima (signifikan).

\section{Pengujian Individu}

Selanjutnya koefisien regresi berganda linier diatas diuji tingkat signifikansinya dengan uji $t$ (test) untuk mengetahui pengaruh variabel bebas secara partial terhadap variabel terikat, sebagai berikut:
- Untuk Variabel KSM

Ho : KSM = 0 (signifikan)

H1: $\mathbf{K S M} \neq \mathbf{O}$ (tidak signifikan)

tabel untuk df $=n-2=167-2=165$, dengan $\alpha=5 \%$ diperoleh $t_{\text {tabel }}=$ 1,651. Dari table 1, thitung diperoleh. = 3,717

thitung berdasarkan uji dua pihak : thitung $<$ ttabel, diterima

- Untuk Variabel Lev

Ho : Lev = 0 (signifikan)

H1: Lev $\neq \mathbf{0}$ (tidak signifikan)

tabel untuk df $=n-2=167-2=165$, uji 1 pihak dengan $\alpha=5 \%$ diperoleh tabel $=1.651$. Dari Tabel 1 thitung diperoleh $=-7,157$

thitung berdasarkan uji dua pihak : $t_{\text {hitung }}<t_{\text {tabel }}$, diterima.

\section{Goodness of fit}

Dari hasil olah data SPSS didapat Rsquare didapat sebesar 0.276 dan $F$ test (uji F): didapat $F_{\text {tabel: }} F_{0.05(2,164)}=3,05$ dan $F_{\text {hitung }} 31.242$ (lihat tabel 2), maka uji $F$ hasilnya $F_{\text {hitung }}>F_{\text {tabel }}$, diterima. Dengan $R^{2}=27.6 \%$ (Tabel 2), hal ini dapat diartikan bahwa sebesar $27.6 \%$ keragaman/variasi dari ROAdapat dijelaskan oleh masuknya kedua variabel dalam model.

\section{Pembahasan}

Hubungan struktur modal dan struktur aset dari hasil analisis korelasi software SPSS versi 18.0 for windows didapat KSM dengan ROA berhubungan negatif dan Lev dengan ROA berhubungan negatif.

Dari model regresi $\mathbf{R O A}=\mathbf{0 . 0 9 4} \mathbf{0 . 1 7 4}$

KSM - 0.114 Lev, didapat bahwa variabel KSM dan Lev mempunyai hubungan negatif dengan ROA. Model regresi diatas dapat diartikan bahwa setiap peningkatan nilai KSM sebesar 1 rupiah, akan memberikan pengaruh negatif terhadap nilai ROA sebesar -.174 rupiah. Demikian halnya peningkatan nilai Lev sebesar 1 rupiah akan member-kan dampak negatif terhadap nilai ROA sebesar 0.114 rupiah

Pengaruh negatif ini membuktikan, apabila penggunaan Utang (Leverage) besar akan menurunkan kemampu labaan perusahaan (ROA). Hal in disebabkan 
karena beban pokok dan bunga pinjaman semakin besar mengurangi ROA. Sebaliknya apabila penggunaan Utang (Leverage) kecil akan meningkatkan kemampu labaan perusahaan (ROA) karena beban pokok dan bunga pinjaman semakin kecil mengurangi ROA.

Demikian halnya apabila KSM besar akan menurunkan kemampu labaan perusahaan (ROA). $\mathrm{Hal}$ in disebabkan karena jumlah kepemilikan yang besar oleh manajer agency cost semakin besar mengurangi ROA. Sebaliknya apabila KSM kecil akan meningkatkan kemampu labaan perusahaan (ROA). Hal in disebabkan karena jumlah kepemilikan yang kecil oleh manajer agency cost semakin kecil mengurangi ROA.

Persamaan regresi dengan memasukkan ketiga variable: KSM, Lev dan ROA menghasilkan $R$ sebesar $52,5 \%$ dengan $R^{2}=27,6 \%$ (Tabel 2 ), hal ini dapat diartikan bahwa sebesar $27,6 \%$ keragaman/variasi dari ROA dapat dijelaskan oleh masuknya kedua variabel dalam model.

Berdasarkan uji statistik parsial (uji t) menggunakan analisis statistik koefisien regresi linier berganda, didapat KSM berpengaruh negatif, dan signifykan terhadap ROA, demikian juga untuk Lev berpengaruh negatif dan signifikan terhadap ROA.

Hasil Rsquare: $R^{2}=27.6 \%$ ini menunjukkan model tidak memenuhi Goodness of fit $\left(\mathrm{R}^{2}<50 \%\right)$, ini berarti variabel yang tidak termasuk dalam model masuk kedalam variabel error.

\section{Kesimpulan}

Sumber pembiayaan perusahaan dari utang (eksternal) dapat dipengaruhi oleh kepemilikan manajer, dimana pada akhirnya utang dan kepe-milikan manajer akan berpengaruh terhadap kemampu labaan perusahaan. Perusahaan yang memiliki aktiva tetap dalam jumlah besar dapat menggunakan utang dalam jumlah yang lebih besar pula. Hal ini disebabkan karena perusahaan yang mempunyai aktiva tetap yang besar dapat digunakan sebagai jaminan atau kolateral utang perusahaan.

Dari hasil olah data dan pembahasan dapat ditarik kesimpulan:

- Dari Tabel 3 Correlations diatas dapat diketahui Kepemilikan Saham Manajer dan Lev berhubungan negatif $(-0,051)$ hasil ini sesuai hipotesis 1 .

- Dari model regresi: $\mathbf{R O A}=0.094-0.174$ KSM - 0.114 Lev (table 1) didapat bahwa variabel KSM dan Utang mempunyai pengaruh yang negatif terhadap ROA hasil ini sesuai hipotesis 2 dan 3 .

\section{Saran}

- Sebaiknya perusahaan manufaktur yang terdaftar di BEl lebih memperhatikan pengelolaan modalnya (struktur pendanaannya), dimana proporsi antara aktiva lancar dan aktiva tetap kurang atau tidak berimbang karena pendanaan internal sebagian besar tertanam di aktiva lancar. Lev perusahaan juga tinggi, jika Lev semakin tinggi kemampuan perusahaan untuk mendapatkan profitability akan semakin rendah. Sebaiknya utang yang dijamin oleh dana internal jangan melebihi jumlah dana internal tersebut, bahkan kalau bisa di bawah $50 \%$ dari jumlah dana internalnya.

- Penilitian ini hanya menggunakan pendanaan eksternal (utang) saja, belum diukur bagaimana pengaruh kepemilikan manajer terhadap equity (pendanaan internal). Model ini tidak memenuhi Goodness of fit $\left(\mathrm{R}^{2}<50 \%\right)$, diharapkan untuk peneliti berikutnya yang mengembangkan penelitian ini menambah observasi sehingga tidak terjadi model tidak memenuhi Goodness of fit.

\section{Daftar Pustaka}

Brigham, Eugene R., and Daves, Phillip R., 2002, Intermediate Financial Management, $8^{\text {th }}$ Edition, Thomson Analytics Business School Edition.

Baridwan, Zaki, 2000, Intermediate Accounting, edisi 7, Yogyakarta BPFE.

Cassar, G. and Holmes S., 2003, Capital structure and financing of SMEs: Australian evidence, Journal of Accounting and Finance 43, pp.123147.

Chittenden, F., Hall, G., \& Hutchinson, P., 1996, Small Firm Growth, Access to Capital Markets and Financial Structure: Review of Issues and an Empirical Investigation, Small Business Economics, 8, pp.59-67.

Esperanca JP, Ana PMG \& Mohamed AG., 2003, Corporate debt policy of small firms: an empirical (re)examination, Journal of Small Business and Enterprise Develop-ment, 10(1), pp.62-80.

Euis Soliha dan Taswan, 2002, "Pengaruh kebijakan hutang terhadap nila perusa-

Finacial Accounting Standards Board (FASB), 1978, Statement of Financial Accounting Concepts No.1: Objectives of Financial Reporting by Business Enterprises, Stamfort, Connecticut 
Holmes, S. and Kent, P., (1991), 'An Empirical Analysis of the Financial Structure of Small and Large Australian Manufacturing Enterprises', Journal of Small Business Finance, 1 (2), pp.141-154.

Jensen, Michael C., 1986, Agency Cost of Free Cash Flow, Corporate Finance, and Take-overs, American Economic Association.

Takarini, Nurjanti dan Erni Ekawati, 2003, "Analisis Rasio Keuangan dalam Memprediksi Perubahan Laba Pada Perusahaan Manufaktur di Pasar Modal Indonesia", Ventura, Vol. 6 No. 3.

Leland, Hayne E., and Pyle, David H., 1977, Informational Asymmetries, Financial Structure and Financial Intermediation, The Journal of Finance, vol.32 no.2, pp.371-387.

Michaelas, N., F. Chittenden, and P. Poutziouris, 1999, Financial policy and capital structure Choice in UK SMEs: Empirical Evidence from Company Panel Data, Small Bu-siness Economics, 12, pp.113-130
Mulyadi (1997). Akuntansi Manajemen: Konsep, manfaat dan rekayasa. (Edisi kedua). Yokyakarta : Bagian Penerbitan Sekolah Tinggi IImu Ekonomi YKPN

Schall and Halley, 1979, The Theory of Financial Decision, New York, McGraw Hill

Titman, S., 1984, The Effect of Capital Structure on a Firm's Liquidation Decisions, Journal of Financial Economics, 13, pp.137-151

Titman, S. and Wessels, R., 1988, "The Determinants of Capital Structure Choice" Journal of Finance", 43(1), pp.1-19.

Van der Wijst, N., \& Thurik, R., 1993, Determinants of Small Firm Debt Ratios: An Analysis of Retail Panel Data. Small Business Economics, 5(1), pp.55-65

Wald, JK., 1999, "How Firm Characteristics Affect Capital Structure: An International Comparison", Journal of Financial Research, 22, pp.161-187. 